\title{
Fetal weight estimation at term - ultrasound versus clinical examination with Leopold's manoeuvres: a prospective blinded observational study
}

Oliver Preyer ${ }^{1 *}$, Heinrich Husslein ${ }^{2}$, Nicole Concin ${ }^{3}$, Anna Ridder $^{4}$, Maciej Musielak ${ }^{1}$, Christian Pfeifer ${ }^{5}$, Willi Oberaigner ${ }^{5,6}$ and Peter Husslein ${ }^{7}$

\begin{abstract}
Background: Fetal weight estimation is of key importance in the decision-making process for obstetric planning and management. The literature is inconsistent on the accuracy of measurements with either ultrasound or clinical examination, known as Leopold's manoeuvres, shortly before term. Maternal BMI is a confounding factor because it is associated with both the fetal weight and the accuracy of fetal weight estimation. The aim of our study was to compare the accuracy of fetal weight estimation performed with ultrasound and with clinical examination with respect to BMI.
\end{abstract}

Methods: In this prospective blinded observational study we investigated the accuracy of clinical examination as compared to ultrasound measurement in fetal weight estimation, taking the actual birth weight as the gold standard.

In a cohort of all consecutive patients who presented in our department from January 2016 to May 2017 to register for delivery at $\geq 37$ weeks, examination was done by ultrasound and Leopold's manoeuvres to estimate fetal weight. All examiners (midwives and physicians) had about the same level of professional experience.

The primary aim was to compare overall absolute error, overall absolute percent error, absolute percent error $>10 \%$ and absolute percent error $>20 \%$ for weight estimation by ultrasound and by means of Leopold's manoeuvres versus the actual birth weight as the given gold standard, namely separately for normal weight and for overweight pregnant women.

Results: Five hundred forty-three patients were included in the data analysis. The accuracy of fetal weight estimation was significantly better with ultrasound than with Leopold's manoeuvres in all absolute error calculations made in overweight pregnant women. For all error calculations performed in normal weight pregnant women, no statistically significant difference was seen in the accuracy of fetal weight estimation between ultrasound and Leopold's manoeuvres.

(Continued on next page)

\footnotetext{
* Correspondence: oliver.preyer@tauernklinikum.at

'Department of Obstetrics and Gynaecology, University Teaching Hospital

Tauernklinikum Zell am See, Paracelsusstrasse 8, A-5700 Zell am See, Austria

Full list of author information is available at the end of the article
}

(c) The Author(s). 2019 Open Access This article is distributed under the terms of the Creative Commons Attribution 4.0 International License (http://creativecommons.org/licenses/by/4.0/), which permits unrestricted use, distribution, and reproduction in any medium, provided you give appropriate credit to the original author(s) and the source, provide a link to the Creative Commons license, and indicate if changes were made. The Creative Commons Public Domain Dedication waiver (http://creativecommons.org/publicdomain/zero/1.0/) applies to the data made available in this article, unless otherwise stated. 
(Continued from previous page)

Conclusions: Data from our prospective blinded observational study show a significantly better accuracy of ultrasound for fetal weight estimation in overweight pregnant women only as compared to Leopold's manoeuvres with a significant difference in absolute error. We did not observe significantly better accuracy of ultrasound as compared to Leopold's manoeuvres in normal weight women. Further research is needed to analyse the situation in normal weight women.

Keywords: Prospective blinded observational study, Ultrasound, Estimated fetal weight, Body mass index, Clinical examination, Fetal weight estimation, Leopold's manoeuvres, Normal weight, Overweight

\section{Background}

Accuracy of fetal weight estimation is of key importance in antenatal care, as well as in the planning and management of labour and mode of delivery [1-9].

In order to achieve more accurate prenatal fetal weight estimations and align these with a risk-optimizing mode of delivery, additional tools supporting the standard of use with ultrasound are needed.

The main ultrasonic methods used to calculate the weight of a fetus are based on measurement of fetal abdominal circumference (AC) and estimated fetal weight (EFW) using a formula first described by Hadlock et al. $[10,11]$, and the sufficient accuracy of this model has recently been proven [12].

Antenatal magnetic resonance imaging (MRI) [13] or soft-tissue measurements [14] have been shown to be of no benefit in improving the accuracy of fetal weight estimation.

Leopold's manoeuvres have a long-standing tradition in obstetrics and midwifery and were first described by the German gynaecologist Christian Gerhard Leopold (1846-1911) in the journal "Archiv für Gynäkologie" in the 19th century [15]. By placing both hands on the woman's abdomen the examiner can describe the position of the fetus as well as the level of the uterine fundus and thus detect a disproportion between fetus and the female pelvis. Experienced examiners are able to give a clinical estimation of fetal weight after performing Leopold's manoeuvres including symphysis-fundal height and abdominal palpation [1].

Maternal body mass index (BMI) has been shown to affect the accuracy of EFW [16]. Clinicians should be aware of the limitation of sonographic fetal weight estimation, especially in obese patients, as maternal body mass index influences sonographic fetal weight estimation prior to scheduled delivery and the measurement deviation is greater in pregnant women with a BMI $\geq 25$ [17-19].

We examined whether clinical assessment is an alternative when ultrasound is not available or can serve as a useful supplemental examination using the actual birth weight as the gold standard. The aim of our prospective blinded observational study was to evaluate the accuracy of fetal weight estimation performed with ultrasound and clinical examination, namely separately for normal weight and for overweight pregnant women.

\section{Methods \\ Study population}

In this prospective blinded observational study we investigated the accuracy of clinical Leopold's manoeuvres as compared to ultrasound measurements in fetal weight estimation, with the actual birth weight as the gold standard.

This is a prospective blinded analysis of a cohort of all consecutive women giving birth, including vertex and breech, singleton gestations who presented for labour $\geq 37$ weeks from January 2016 to May 2017 at our department.

To avoid selection bias and perform a real live evaluation, we examined all consecutive women registered for delivery and ultimately delivered at $\geq 37$ weeks. No preterm deliveries prior to 37 weeks are done at our department, but are sent antenatally to a secondary referral centre. Therefore, there are no data on preterm deliveries in our data set.

Cases of both spontaneous labour and induction of labour were included as well as planned (primary) and unplanned (secondary) caesarean sections (see Table 1). No fetal abnormalities were detected in our group of pregnant women.

The results were documented systematically during and analysed after the study period. All data were analysed in anonymized form. We did not change the pre-existing routine examination.

\section{Clinical setting and fetal weight estimation by ultrasound} and Leopold's manoeuvres

At our institution the standard of care consists of registering pregnant women for delivery around the 37th week of their pregnancy.

The clinical setting at registration for delivery is as follows: 1.) Patient's history taken by examining midwife; 2.) Cardiotocography (CTG) for $30 \mathrm{~min}$ in pregnant women at risk; 3) basic obstetric vaginal and abdominal 
Table 1 Patient characteristics

\begin{tabular}{|c|c|c|}
\hline & $n=543$ & $\%$ \\
\hline Maternal Age & $29.2 \pm 5.0$ & \\
\hline Primiparous & 269 & 49.5 \\
\hline Multiparous & 274 & 50.5 \\
\hline $\begin{array}{l}\text { Mean gestational } \\
\text { age at examination } \\
\text { [Weeks } \pm \text { SD in days] }\end{array}$ & $\begin{array}{l}37+3 / 7 \\
(262 d) \pm 6.8 d\end{array}$ & \\
\hline $\begin{array}{l}\text { Mean gestational age } \\
\text { at time of delivery } \\
\text { [weeks } \pm \text { SD in days] }\end{array}$ & $\begin{array}{l}39+2 / 7 \\
(275 d) \pm 8 d\end{array}$ & \\
\hline $\begin{array}{l}\text { Mean actual birth } \\
\text { weight [g] }\end{array}$ & $3382.9 \pm 400.2$ & \\
\hline $\begin{array}{l}\text { Median time estimation } \\
\text { to birth [in days } \pm \text { SD] }\end{array}$ & $15.6 \pm 8$ & \\
\hline \multicolumn{3}{|l|}{ Mode of delivery } \\
\hline $\begin{array}{l}\text { Spontaneous } \\
\text { vaginal delivery }\end{array}$ & 342 & 63.0 \\
\hline Operative vaginal delivery & 45 & 8.3 \\
\hline Caesarean section & $156(100 \%)$ & 28.7 \\
\hline Planned/Primary & $57(36.5 \%)$ & 10.5 \\
\hline $\begin{array}{l}\text { Unplanned/Secondary } \\
\text { (including failed } \\
\text { induction of labour) }\end{array}$ & $99(63.5 \%)$ & 18.2 \\
\hline $\begin{array}{l}\text { Mean maternal BMl } \\
{\left[\mathrm{kg} / \mathrm{m}^{2}\right]}\end{array}$ & $23.9 \pm 4.8$ & \\
\hline $\mathrm{BMI}<25$ & 379 & 69.8 \\
\hline BMI 25-99 & 164 & 30.2 \\
\hline Spontaneous onset of labour & 429 & 79.0 \\
\hline Induced onset of labour & 114 & 21.0 \\
\hline Gestational diabetes & 29 & 5.3 \\
\hline Pre-existing diabetes & 2 & 0.4 \\
\hline $\begin{array}{l}\text { Chronic or gestational } \\
\text { hypertension }\end{array}$ & 9 & 1.7 \\
\hline Preeclampsia & 13 & 2.4 \\
\hline
\end{tabular}

examination with Leopold's manoeuvres by midwife and documentation of EFW (blinded to the physician (sonographer)); 4) ultrasound biometric measurements (GE@ E6, 3.5-MHz abdominal transducer) of the fetus by the physician (one of six consultants or one of two residents) including EFW (blinded to the examining midwife) registered in a nationwide electronic documentary system (PIA/Viewpoint $\odot$ by LB-Systems $\odot$ ); 5) pre-delivery discussion with the physician regarding possible risks and mode of delivery.

Both the midwife and the physician (sonographer) were blinded to the documentation of the weight of prior babies, and pregnant women were asked not to disclose this information to avoid bias.

Every Friday, after the last delivery registration appointment of the week, the measurements were released for comparison. If discrepancies were noticed (>500 g), these pregnant women were asked to return for re-counselling. Decisions were then based on the ultrasound measurements and their interpretation by a consultant.

Calculation by the ultrasound machine and the PIA/ Viewpoint $($ ) system is based on Hadlock's formula [10] including measurement of biparietal diameter (BPD), head circumference $(\mathrm{HC})$, abdominal circumference $(\mathrm{AC})$ and femur length (FL). The results are discussed in a shared decision-making process between the examiner and the mother/parents to plan the mode of delivery.

Fetal weight estimation by midwives using Leopold's manoeuvres is provided as a point estimate rounded off to the nearest $100 \mathrm{~g}$ by the examining midwife.

All examiners, 13 midwives, six consultants and two residents had a level of professional experience of at least 3 years, as both residents were in their fourth and last year of residency. The range of experience among midwives was 5 years to up to 34 years (mean 16.6), among consultants and residents between four and 34 years (mean 11.8).

As previously mentioned, we did not change the preexisting routine examination, and the midwives already performed Leopold's manoeuvres as a non-invasive examination for fetal weight estimation before we started our study. The institutional review board (IRB) decision was obtained from the Tauernkliniken GmbH IRB before recruitment for the full trial began in December 2015 (Ref.nr. IRB TK 01_10/2015). All women gave verbal informed consent to participate, which was recorded in the patient's records.

Maternal demographics as well as pregnancy and neonatal outcome information were extracted from electronic medical records (PIA/Viewpoint $\odot$ by LB-Systems $\odot$ ).

In order to extrapolate EFW (Leopold and US) from the examination on the date of birth registration to the actual date of birth, we used the complementary percentile curve for the Austrian population (separately available for girls and boys) (Heim et al., unpublished data).

BMI was evaluated for its impact on clinical estimation of fetal weight. Maternal BMI was calculated from height (self-reported) and weight (measured) at the time of admission and was divided into sub-categories of $<25 \mathrm{~kg} / \mathrm{m}^{2}$ and $\geq 25 \mathrm{~kg} / \mathrm{m}^{2}$.

Gestational age at registration for delivery was evaluated in intervals of 37 to $396 / 7$ weeks, 40 to $406 / 7$ weeks, and $\geq 41$ weeks.

The outcome was to compare overall absolute error, overall absolute percent error, absolute percent error $>10 \%$ and absolute percent error $>20 \%$ for weight estimation by ultrasound and by Leopold's manoeuvres versus the actual birth weight as the given gold standard. The estimations and extrapolations were performed according to validated methods to the best of our knowledge. The median time between estimation and birth is shown in Table 1 . 


\section{Statistical analysis}

Baseline characteristics of the study cohort were reported using descriptive statistics.

We calculated the mean and standard deviation (SD) of maternal age (years), duration of pregnancy (weeks + 6/7 days), fetal weight at birth (grams), body mass index (BMI) $\left(\mathrm{kg} / \mathrm{m}^{2}\right)$, parity, mode of delivery (spontaneous, vaginal operative, Caesarean section), induction of labour and maternal risk factors (gestational diabetes, hypertension, preeclampsia) for univariate descriptive analysis ("patient characteristics"). Absolute errors (equal to the absolute value of the difference between the estimate and the observed weight at birth date) in the estimates were calculated, reporting the mean and SD for the Leopold and the US estimates. It seemed to be practice-relevant to report the proportion of cases with an absolute error $\geq 500 \mathrm{~g}$ [20]. Additionally, we report absolute percent errors (mean SD), absolute percent errors $>10 \%$ and absolute percent errors $>20 \%$.

To test for differences in the absolute errors and the absolute percent errors between Leopold and ultrasound estimates we used the paired $\mathrm{T}$ test. For the proportion of absolute errors $\geq 500 \mathrm{~g}$, absolute percent error $>10 \%$ and absolute percent error $>20 \%$ we used the McNemar test statistics for paired samples.

We conducted the above analysis separately for normal weight and for overweight pregnant women.

In order to investigate the effects of BMI on estimate errors, we performed a descriptive analysis as described above, namely separately for the two groups (using two sample tests instead of paired tests). We stratified the results for BMI for $<25 \mathrm{~kg} / \mathrm{m}^{2}$ (normal weight) and $\geq 25 \mathrm{~kg} / \mathrm{m}^{2}$ (overweight).

Normality test was applied first by visual inspection of the respective histograms and then formally by applying the Shapiro-Wilk Test.

All statistical analyses were performed using Stata/SE 13.1, Special Edition (College Station, TX, USA).

\section{Results}

\section{Patient characteristics}

A total of 547 pregnant women were eligible to be included, four pregnant women had to be excluded as they gave birth at a different department after registration at our department. Therefore, 543 pregnant women were included in the data analysis. Of the pregnant women in our cohort 5.3\% had gestational diabetes. Due to mandatory gestational diabetes screening during pregnancy in Austria and a close follow-up after registration for delivery at our department, which may represent a situation different from that in other countries, we are able to state that these $5.3 \%$ pregnant women with gestational diabetes in our cohort were exactly monitored with blood sugar testing. Due to normal results in all 29 patients, who had either diet or insulin, the pregnancies with gestational diabetes in our cohort were comparable to normal pregnancies.

Patient characteristics can be found in Table 1 .

Fetal weight estimation: ultrasound versus Leopold's manoeuvres.

No statistically significant difference was seen in the accuracy of fetal weight estimation performed with Leopold's manoeuvres versus ultrasound in any absolute error calculations of normal weight women giving birth. This can be seen from Table 2 at the time of delivery registration.

A statistically significant difference in the accuracy of fetal weight estimation was observed in favour of ultrasound in all absolute error calculations performed in overweight women giving birth. This can be seen from Table 3 at the time of delivery registration.

A statistically significant difference in the accuracy of fetal weight estimation was observed in favour of ultrasound in all absolute error calculations performed in all women giving birth. This can be seen from Table 4 at the time of delivery registration.

Density of distribution of estimated fetal weight as compared to actual birthweight established by ultrasound versus palpation is shown in Fig. 1. The data in the present study show that the estimates made by the examiners, whether physicians or midwives, whether with ultrasound or clinical palpation, were close together in normal weight women.

Fetal weight estimations of normal weight and overweight women with either Leopold's manoeuvres or ultrasound displaying absolute error, absolute error $>500 \mathrm{~g}$,

Table 2 Accuracy of both weight estimations regarding effective birth weight in all normal weight pregnant women

\begin{tabular}{llll}
\hline EFW & Leopold's manoeuvres & Ultrasound & $p$ value \\
\hline Absolute error $[\mathrm{g}]$ & $279 \pm 225$ & $257 \pm 204$ & $0.0696^{\mathrm{a}}$ \\
Absolute error $>$ 500g [\%] & 17.2 & 12.9 & $0.0805^{\mathrm{b}}$ \\
Absolute \% error $[\mathrm{g}]$ & $8.6 \pm 7.5$ & $7.9 \pm 6.5$ & $0.051^{\mathrm{a}}$ \\
Absolute \% error $>10 \%[\%]$ & 33.5 & 29.6 & $0.155^{\mathrm{b}}$ \\
Absolute \% error $>$ 20\% [\%] & 7.1 & 6.9 & $1.0^{\mathrm{b}}$ \\
\hline
\end{tabular}

a Paired T test, ${ }^{b}$ Exact McNemar test 
Table 3 Accuracy of both weight estimations regarding actual birth weight in all overweight pregnant women

\begin{tabular}{llll}
\hline EFW & Leopold's manoeuvres & Ultrasound & $p$ value \\
\hline Absolute error [g] & $343 \pm 250$ & $245 \pm 190$ & $<0.001^{a}$ \\
Absolute error $>$ 500g [\%] & 22.6 & 9.1 & $0.0002^{b}$ \\
Absolute \% error $[\mathrm{g}]$ & $10.1 \pm 7.8$ & $7.3 \pm 6.1$ & $<0.001^{\mathrm{a}}$ \\
Absolute \% error $>10 \%[\%]$ & 42.1 & 24.4 & $0.0002^{\mathrm{b}}$ \\
Absolute \% error $>$ 20\% [\%] & 12.8 & 4.3 & $0.0026^{\mathrm{b}}$ \\
\hline
\end{tabular}

a Paired T test, ${ }^{b}$ Exact McNemar test

absolute percent error, absolute error $>10 \%$ and absolute error $>20 \%$, including $95 \%$ confidence intervals $( \pm 95 \%$ CI) are shown in detail in Fig. 2a-e.

\section{Discussion \\ Main findings}

In this prospective blinded observational study we found a statistically significant difference in the accuracy of fetal weight estimation in favour of ultrasound in all absolute error calculations performed in overweight women giving birth, however no statistically significant difference in normal weight women giving birth.

With regard to the mode of delivery and exact timing in the event that it is necessary to induce labour, the accuracy of fetal weight estimation is of key importance in the obstetrician's decision-making process shared with the expectant mother and has been a matter of discussion for many years [21].

A deviation of $500 \mathrm{~g}$ could have a significant impact on the shared decision-making process, particularly with regard to cut-off levels given in international guidelines [20,21].

\section{Interpretation in light of other evidence}

First, our study demonstrates a statistically significant difference in the accuracy of fetal weight estimation in favour of ultrasound in all absolute error calculations made in overweight women giving birth. With regard to an absolute error $>500 \mathrm{~g}$ that is clinically relevant for the obstetric decision-making process, a significant difference was evident between the two methods when used in overweight pregnant women.
These results are in line with previously published data [22-24].

Second, no statistically significant difference was seen in the accuracy of fetal weight estimation obtained with Leopold's manoeuvres versus ultrasound in absolute error calculations performed in normal weight women giving birth.

The most established way to estimate fetal weight is the ultrasound method, as previously described [10-12] and most commonly performed with three measurements fitted into an algorithm designed by Hadlock et al. [10]. Other approaches like MRI or soft-tissue measurements have proved to not be of added benefit $[13,14]$.

International percentile curves for EFW, calculated after studies of fetuses in Anglo-Saxon countries and used to check the week-adapted weight of the unborn fetuses worldwide, may not be the right strategy because they pursue a one-size-fits-all policy in approaching what is too large or too small $[25,26]$.

Very recently Nicolaides et al. [27] published a study aiming to develop fetal and neonatal population weight charts. The rationale was that reference ranges of EFW are representative for the whole population, while the traditional approach of deriving birth-weight (BW) charts is misleading, because a large proportion of babies born preterm arises from pathological pregnancy [27]. The study qualified that the desire for a single international standard for all countries is not appropriate [27]. This has been demonstrated in different studies before by likely differences in percentile curves as a consequence of underlying differences in the study populations [28, 29].

The long-standing, mainly midwifery-based tradition of clinical weight estimation by means of

Table 4 Accuracy of both weight estimations regarding actual birth weight in all pregnant women

\begin{tabular}{llll}
\hline EFW & Leopold's manoeuvres & Ultrasound & $p$ value \\
\hline Absolute error [g] & $298 \pm 235$ & $254 \pm 200$ & $<0.001^{a}$ \\
Absolute error $>$ 500g [\%] & 18.8 & 11.8 & $0.0003^{\mathrm{b}}$ \\
Absolute \% error [g] & $9.1 \pm 7.6$ & $7.7 \pm 6.4$ & $<0.001^{\mathrm{a}}$ \\
Absolute \% error $>10 \%[\%]$ & 36.1 & 28.0 & $0.0004^{\mathrm{b}}$ \\
Absolute \% error $>$ 20\% [\%] & 8.8 & 6.1 & $0.036^{\mathrm{b}}$ \\
\hline
\end{tabular}

apaired T test, ${ }^{\mathrm{b}}$ Exact McNemar test 


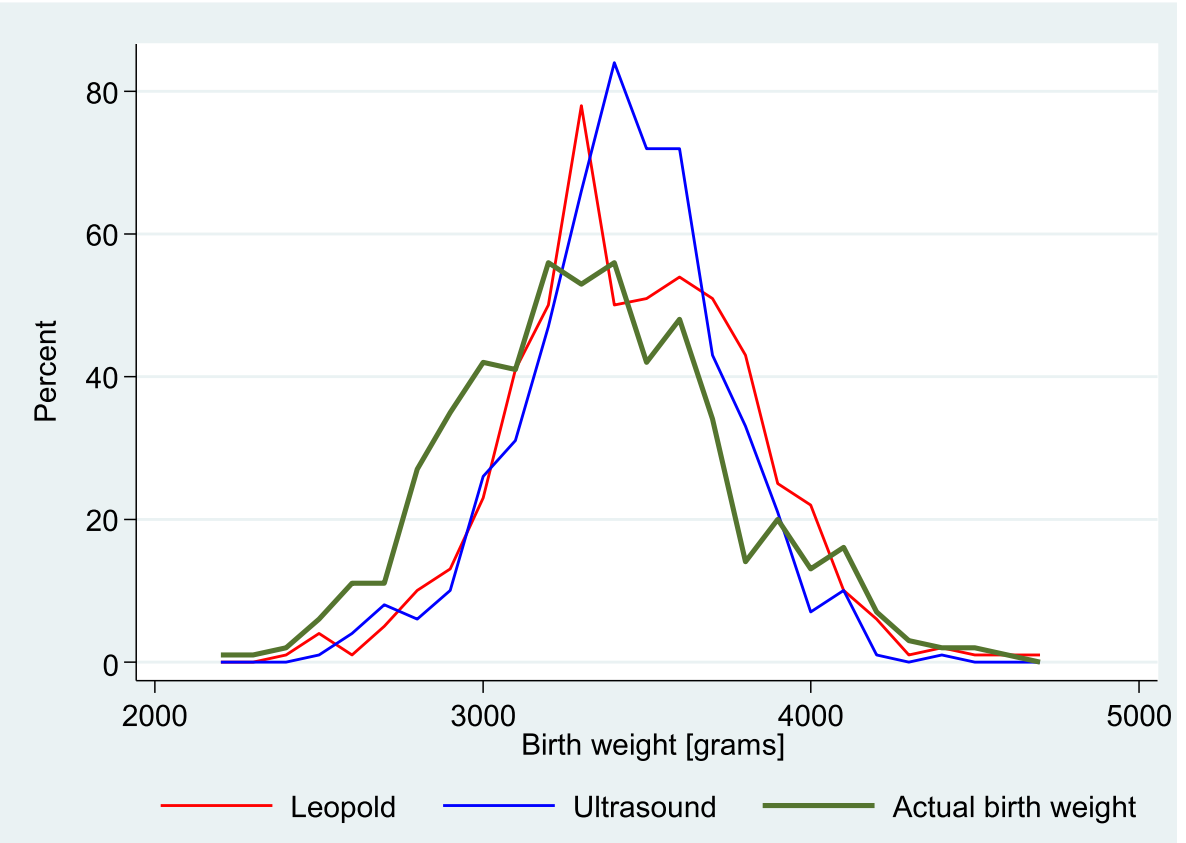

Fig. 1 Estimated fetal weight from the time of examination in relation to the actual birth weight

a

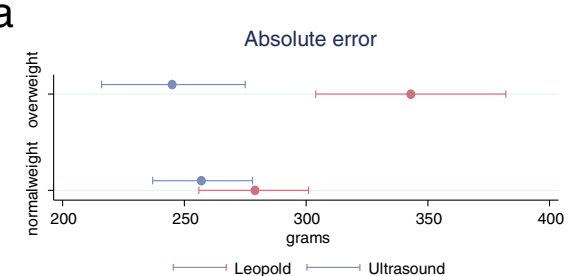

C

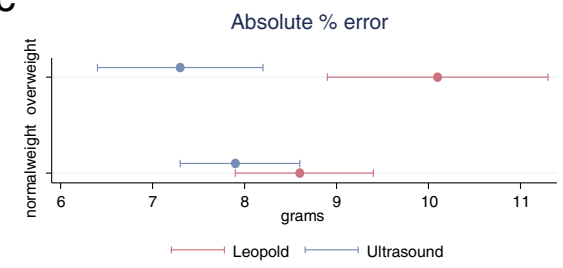

d

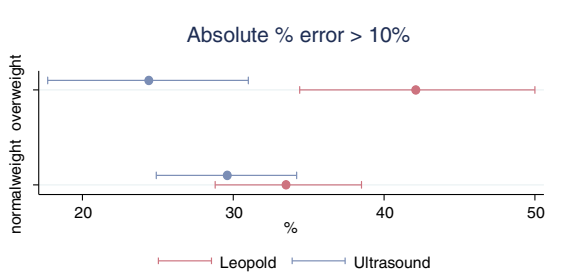

b

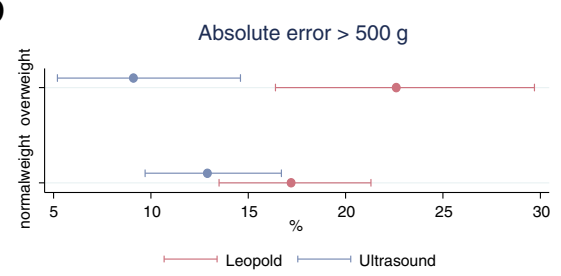

e

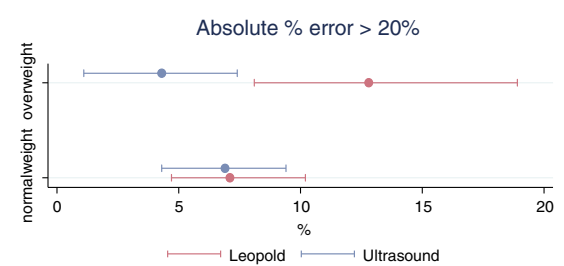

Fig. 2 a) Absolute error of estimated fetal weight $( \pm 95 \% \mathrm{Cl}$ ), b) Absolute error $>500 \mathrm{~g}$ of estimated fetal weight $( \pm 95 \% \mathrm{Cl})$, c) Absolute $\%$ error of estimated fetal weight $( \pm 95 \% \mathrm{Cl})$, d) Absolute $\%$ error $>10 \%$ of estimated fetal weight $( \pm 95 \% \mathrm{Cl})$, e) Absolute $\%$ error $>20 \%$ of estimated fetal weight $( \pm 95 \% \mathrm{Cl})$ in normal weight and overweight women with Leopold's maneuvers or ultrasound 
Leopold's manoeuvres is a non-invasive approach to fetal weight estimation that is used when ultrasound is not available $[1,15]$.

The conclusions published in the literature regarding fetal weight estimation are inconsistent, with some studies favouring ultrasound measurement [30-34]. Goetzinger et al. reported a lack of accuracy in fetal weight estimation when using Leopold's manoeuvres [35]. Several prospective studies were able to show advantages of clinical palpation like Leopold's manoeuvres in predicting fetal macrosomia $[14,26,36,37]$, and the accuracy of fetal weight estimation when using ultrasound biometry has been shown to be no better than that of Leopold's manoeuvres [21]. Still other studies report an advantage for them for fetal weight estimation [38-44].

High incongruence of study designs and the difference in approaches regarding time of examination, extrapolation of absolute error in matters of actual birth weight, examiner's experience etc. might explain the variety of different results obtained.

As several studies have shown body mass index (BMI) to affect the accuracy of EFW [16-19], we decided to stratify between normal weight and overweight pregnant women in our cohort.

We found a significant difference between ultrasound and clinical palpation with Leopold's manoeuvres regarding fetal weight estimation in overweight pregnant women.

The difficulty of obstetric ultrasound examinations mostly grows with increasing maternal BMI due to diminished visualization, but its impact on fetal weight estimation is described controversially in the existing literature [19, 22, 23].

Furthermore, we found no significant difference between clinical palpation with Leopold's manoeuvres and ultrasound for fetal weight estimation in normal weight pregnant women.

Our study included women who gave birth within the mean time of 13 days after fetal weight estimation. Some study data and systematic review results show that the most accurate estimates can be expected between four and 7 days before delivery [45-47]. Nevertheless, we did not change our management procedures and estimated fetal weight pragmatically at registration for delivery. Furthermore, fetal weight estimation at term is suspected of doing more harm than good and is the matter of ongoing peer discussion very recently [48].

In this connection we used the most recent Austrian percentile curves for the expected actual birth weight (Heim et al., in submission) and compared them with the actual birth weight to validate the measurement results. Several studies previously showed that Hadlock's formula is the most consistently used for normal clinical cohorts [12, 49].

\section{Strengths and limitations}

The strengths of our study are that we present prospective data resulting from a pragmatic assessment of pregnant women as they arrived at our department for delivery, representing a normal life situation. Furthermore, the stratification of normal weight and overweight women regarding the effect of BMI on the accuracy of EFW is the major contribution of our study to the existing literature. In the analysis we included all consecutive women giving birth at our department, thus avoiding a selection bias.

A limitation of our study is the borderline significance of errors in the group of normal weight pregnant women, which might become significant for a larger pool of patients.

We did not investigate inter-observer variation. The time interval between estimation and delivery represents the real life clinical setting at our department.

\section{Conclusions}

The data obtained in our prospective blinded observational study show ultrasound to have a significantly better accuracy in fetal weight estimation in overweight pregnant women than Leopold's manoeuvres. However, no statistically significant difference between the two methods was observed in normal weight pregnant women.

The clinical method using Leopold's manoeuvres might be useful in countries with poor infrastructure and thus poor availability of ultrasound devices.

\section{Abbreviations \\ AC: Abdominal circumference; AC: Abdominal circumference; BMl: Body mass index; BPD: Biparietal diameter; BW: Birth weight; Cl: Confidence intervals; CTG: Cardiotocography; EFW: Estimated fetal weight; FL: Femur length; g: grams; HC: Head circumference; IRB: Institutional review board; \\ SD: Standard deviation; TK: Tauernkliniken}

Acknowledgements

We acknowledge the services of Mary Heaney Margreiter for professional language editing.

\section{Funding}

None.

Availability of data and materials

All data generated or analysed during this study are included in this published article (Results section and tables within the manuscript).

\section{Authors' contributions}

Conception: OP, HH, NC, CP, WO, PH. Planning: OP, HH, NC, CP, WO, PH. Execution: $O P, A R, M M$, WO. Analysis: $C P, W O$. Writing up the manuscript: $O P$, $\mathrm{HH}, \mathrm{NC}$, WO. Critical revision of the manuscript: OP, HH, NC, AR, MM, CP, WO, $\mathrm{PH}$. All authors read and approved the final manuscript.

\section{Ethics approval and consent to participate}

The institutional review board (IRB) decision was obtained from the Tauernkliniken $\mathrm{GmbH}$ IRB before recruitment for the full trial began in December 2015 (Ref.nr. IRB TK 01_10/2015). All women gave verbal informed consent to participate, which was recorded in the patients' records. The ethics committee formally approved the verbal informed consent. 


\section{Consent for publication}

Not applicable since data were anonymized and no data on a specific participant are presented.

\section{Competing interests}

The authors declare that they have no competing interests.

\section{Publisher's Note}

Springer Nature remains neutral with regard to jurisdictional claims in published maps and institutional affiliations.

\section{Author details}

'Department of Obstetrics and Gynaecology, University Teaching Hospital Tauernklinikum Zell am See, Paracelsusstrasse 8, A-5700 Zell am See, Austria. 2 Department of Obstetrics and Gynaecology, Division of General Gynaecology and Gynaecologic Oncology, Medical University of Vienna Waehringer Guertel 18-20, A-1090 Vienna, Austria. ${ }^{3}$ Department of Obstetrics and Gynaecology, Medical University of Innsbruck, Anichstrasse 35, A-6020 Innsbruck, Austria. ${ }^{4}$ Paracelsus Medical University, Strubergasse 21, A-5020 Salzburg, Austria. ${ }^{5}$ Department of Clinical Epidemiology of the Tyrolean State Hospitals Ltd, Cancer Registry of Tyrol, Tirolkliniken GmbH, Anichstrasse 35, A-6020 Innsbruck, Austria. ${ }^{6}$ Department of Public Health, Health Services Research and Health Technology Assessment, Institute of Public Health, Medical Decision Making and HTA, UMIT The Health \& Life Sciences University, Eduard-Wallnöfer-Zentrum 1, A-6060 Hall in Tirol, Austria ${ }^{7}$ Department of Obstetrics and Gynaecology, Division of Obstetrics and Fetomaternal Medicine, Medical University of Vienna, Waehringer Guertel 18-20, A-1090 Vienna, Austria.

\section{Received: 16 September 2018 Accepted: 18 March 2019}

\section{Published online: 11 April 2019}

\section{References}

1. Ray EM, Alhusen JL. The suspected Macrosomic fetus at term: a clinical Dilemma. J Midwifery Womens Health. 2016;61:263-9. https://doi.org/10. 1111/jmwh.12414.

2. Frick AP, Syngelaki A, Zheng M, Poon LC, Nicolaides KH. Prediction of largefor-gestational-age neonates: screening by maternal factors and biomarkers in the three trimesters of pregnancy. Ultrasound Obstet Gynecol. 2016;47: 332-9. https://doi.org/10.1002/uog.15780.

3. Boulet SL, Alexander GR, Salihu HM, Pass M. Macrosomic births in the United States: determinants, outcomes, and proposed grades of risk. Am J Obstet Gynecol. 2003;188:1372-8. https://doi.org/10.1067/mob.2003.302.

4. Bjørstad AR, Irgens-Hansen K, Daltveit AK, Irgens LM. Macrosomia: mode of delivery and pregnancy outcome. Acta Obstet Gynecol Scand. 2010;89:6649. https://doi.org/10.3109/00016341003686099.

5. King JR, Korst LM, Miller DA, Ouzounian JG. Increased composite maternal and neonatal morbidity associated with ultrasonographically suspected fetal macrosomia. J Matern Fetal Neonatal Med. 2012;25:1953-9. https://doi.org/ 10.3109/14767058.2012.674990.

6. Zhang X, Decker A, Platt RW, Kramer MS. How big is too big? The perinatal consequences of fetal macrosomia. Am J Obstet Gynecol. 2008;198:517.e16. https://doi.org/10.1016/j.ajog.2007.12.005.

7. Esakoff TF, Cheng YW, Sparks TN, Caughey AB. The association between birthweight $4000 \mathrm{~g}$ or greater and perinatal outcomes in patients with and without gestational diabetes mellitus. Am J Obstet Gynecol. 2009;200:672. e1-4. https://doi.org/10.1016/j.ajog.2009.02.035.

8. Gupta N, Kiran TU, Mulik V, Bethel J, Bhal K. The incidence, risk factors and obstetric outcome in primigravid women sustaining anal sphincter tears. Acta Obstet Gynecol Scand. 2003;82:736-43. https://doi.org/10.1034/j.16000412.2003.00179.x

9. Casey BM, Schaffer Jl, Bloom SL, Heartwell SF, McIntire DD, Leveno KJ. Obstetric antecedents for postpartum pelvic floor dysfunction. Am J Obstet Gynecol. 2005;192:1655-62. https://doi.org/10.1016/j.ajog.2004.11.031.

10. Hadlock FP, Harrist RB, Sharman RS, Deter RL, Park SK. Estimation of fetal weight with the use of head, body, and femur measurements--a prospective study. Am J Obstet Gynecol. 1985;151:333-7 PMID: 3881966

11. Deter RL, Hadlock FP. Use of ultrasound in the detection of macrosomia: a review. J Clin Ultrasound. 1985;13:519-24. PMID: 3934213.

12. Hammami A, Mazer Zumaeta A, Syngelaki A, Akolekar R, Nicolaides KH. Ultrasonographic estimation of fetal weight: development of new model and assessment of performance of previous models. Ultrasound Obstet Gynecol. 2018;52:35-43. https://doi.org/10.1002/uog.19066.

13. Malin GL, Bugg GJ, Takwoingi Y, Thornton JG, Jones NW. Antenatal magnetic resonance imaging versus ultrasound for predicting neonatal macrosomia: a systematic review and meta-analysis. Br J Obstet Gynaecol. 2016:123:77-88. https://doi.org/10.1111/1471-0528.13517.

14. Chauhan SP, West DJ, Scardo JA, Boyd JM, Joiner J, Hendrix NW. Antepartum detection of macrosomic fetus: clinical versus sonographic, including soft-tissue measurements. Obstet Gynecol. 2000;95:639-42 PMID: 10775720.

15. Leopold G, Spörlin N. Die Leitung der regelmäßigen Geburten nur durch äußere Untersuchung. Arch Gynakol. 1894;45:337-68. (German).

16. Lanowski JS, Lanowski G, Schippert C, Drinkut K, Hillemanns P, Staboulidou I. Ultrasound versus clinical examination to estimate fetal weight at term. Geburtshilfe Frauenheilkd. 2017;77:276-83. https://doi. org/10.1055/s-0043-102406.

17. Paganelli S, Soncini E, Comitini G, Palomba S, La Sala GB. Sonographic fetal weight estimation in normal and overweight/obese healthy term pregnant women by gestation-adjusted projection (GAP) method. Arch Gynecol Obstet. 2016;293:775-81. https://doi.org/10.1007/s00404-015-3910-z.

18. Aksoy H, Aksoy Ü, Karadağ Öi, Yücel B, Aydın T, Babayiğit MA. Influence of maternal body mass index on sonographic fetal weight estimation prior to scheduled delivery. J Obstet Gynaecol Res. 2015;41:1556-61. https://doi.org/ 10.1111/jog.12755.

19. Fox NS, Bhavsar V, Saltzman DH, Rebarber A, Chasen ST. Influence of maternal body mass index on the clinical estimation of fetal weight in term pregnancies. Obstet Gynecol. 2009;113:641-5. https://doi.org/10.1097/AOG. Ob013e3181998eef.

20. S1-Leitlinie DGGG: Vorgehen bei Terminüberschreitung und Übertragung. AWMF 015/65 (Leitliniensammlung der DGGG), 2018. https://www.awmf. org/leitlinien/detail/I//015-065.html. (German).

21. American College of Obstetricians and Gynecologists' Committee on Practice Bulletins-Obstetrics. Practice bulletin no. 173: fetal Macrosomia. Obstet Gynecol. 2016;128:1191-2. https://doi.org/10.1097/AOG. 0000000000001767.

22. Field NT, Piper JM, Langer $O$. The effect of maternal obesity on the accuracy of fetal weight estimation. Obstet Gynecol. 1995;86:102-7. https://doi.org/ 10.1016/0029-7844(95)00096-A.

23. Farrell $T$, Holmes $R$, Stone $P$. The effect of body mass index on three methods of fetal weight estimation. Br J Obstet Gynaecol. 2002;109:651-7. https://doi.org/10.1111/j.1471-0528.2002.01249.x.

24. Heer IM, Kumper C, Vogtle N, Muller-Egloff S, Dugas M, Strauss A. Analysis of factors influencing the ultrasonic fetal weight estimation. Fetal Diagn Ther 2008:23:204-10. https://doi.org/10.1159/000116742.

25. Reboul Q, Delabaere A, Luo ZC, Nuyt AM, Wu Y, Chauleur C, et al. Prediction of small-for-gestational-age neonate by third-trimester fetal biometry and impact of ultrasound-delivery interval. Ultrasound Obstet Gynecol. 2017;49: 372-8. https://doi.org/10.1002/uog.15959.

26. Grantz KL, Kim S, Grobman WA, Newman R, Owen J, Skupski D, et al. Feta growth velocity: the NICHD fetal growth studies. Am J Obstet Gynecol. 2018:219:285.e1-285.e36. https://doi.org/10.1016/j.ajog.2018.05.016.

27. Nicolaides KH, Wright D, Syngelaki A, Wright A, Akolekar R. Fetal Medicine Foundation fetal and neonatal population weight charts. Ultrasound Obstet Gynecol. 2018;52:44-51. https://doi.org/10.1002/uog.19073.

28. Stirnemann J, Villar J, Salomon L, Ohuma E, Ruyan P, Altman DG, International Fetal and Newborn Growth Consortium for the 21st Century (INTERGROWTH-21st); Scientific Advisory Committee; Steering Committees; INTERGROWTH-21st; INTERBIO-21st; Executive Committee; In addition for INTERBIO 21st; Project Coordinating Unit; Data Analysis Group; Data Management Group; In addition for INTERBIO 21st; Ultrasound Group; In addition for INTERBIO-21st:; Anthropometry Group; In addition for INTERBIO21st:; Laboratory Processing Group; Neonatal Group; Environmental Health Group; Neurodevelopment Group; Participating countries and local investigators; In addition for INTERBIO-21st:; In addition for INTERBIO-21st, et al. International estimated fetal weight standards of the INTERGROWTH21(st) Project. Ultrasound Obstet Gynecol. 2017;49:478-86. https://doi.org/ 10.1002/uog.17347.

29. Kiserud T, Piaggio G, Carroli G, Widmer M, Carvalho J, Neerup Jensen L, et al. The World Health Organization fetal growth charts: a multinational longitudinal study of ultrasound biometric measurements and estimated fetal weight. PLoS Med. 2017;14:e1002220. https://doi.org/10.1371/journal.pmed.1002220. 
30. Nguyen T, Hawkins CJ, Amon E, Gavard J. Effect of maternal weight on accuracy of maternal and physician estimate of fetal weight. J Reprod Med. 2013;58:200-4. PMID: 23763003.

31. Hirata Gl, Medearis AL, Horenstein J, Bear MB, Platt LD. Ultrasonographic estimation of fetal weight in the clinically macrosomic fetus. Am J Obstet Gynecol. 1990;162:238-42. https://doi.org/10.1016/0002-9378(90)90857-4.

32. Shamley KT, Landon MB. Accuracy and modifying factors for ultrasonographic determination of fetal weight at term. Obstet Gynecol. 1994;84:926-30 PMID: 7970471

33. Dar P, Weiner I, Sofrin O, Sachs GS, Bukovsky I, Arieli S. Clinical and sonographic fetal weight estimates in active labor with ruptured membranes. J Reprod Med. 2000;45:390-4. PMID: 10845172.

34. Chien PF, Owen P, Khan KS. Validity of ultrasound estimation of fetal weight. Obstet Gynecol. 2000;95:856-60 PMID: 10831981.

35. Goetzinger KR, Odibo AO, Shanks AL, Roehl KA, Cahill AG. Clinical accuracy of estimated fetal weight in term pregnancies in a teaching hospital. $J$ Matern Fetal Neonatal Med. 2014;27:89-93. https://doi.org/10.3109/ 14767058.2013 .806474

36. Chauhan SP, Cowan BD, Magann EF, Bradford TH, Roberts WE, Morrison JC Intrapartum detection of a macrosomic fetus: clinical versus 8 sonographic models. Aust N Z J Obstet Gynaecol. 1995;35:266-70. https://doi.org/10. 1111/j.1479-828X.1995.tb01978.X.

37. Weiner Z, Ben-Shlomo I, Beck-Fruchter R, Goldberg Y, Shalev E. Clinical and ultrasonographic weight estimation in large for gestational age fetus. Eur Obstet Gynecol Reprod Biol. 2002;105:20-4. https://doi.org/10.1016/S03012115(02)00140-9.

38. Khani S, Ahmad-Shirvani M, Mohseni-Bandpei MA, MohammadpourTahmtan RA. Comparison of abdominal palpation, Johnson's technique and ultrasound in the estimation of fetal weight in northern Iran. Midwifery. 2011;27:99-103. https://doi.org/10.1016/j.midw.2009.10.005.

39. Mehdizadeh A, Alaghehbandan R, Horsan H. Comparison of clinical versus ultrasound estimation of fetal weight. Am J Perinatol. 2000;17:233-6. https:// doi.org/10.1055/s-2000-10003.

40. Hendrix NW, Grady CS, Chauhan SP. Clinical vs. sonographic estimate of birth weight in term parturients. A randomized clinical trial. J Reprod Med. 2000;45:317-22. PMID: 10804488.

41. Titapant V, Chawanpaiboon S, Mingmitpatanakul K. A comparison of clinical and ultrasound estimation of fetal weight. J Med Assoc Thail. 2001;84:12517 PMID: 11800297

42. Ashrafganjooei T, Naderi T, Eshrati B, Babapoor N. Accuracy of ultrasound, clinical and maternal estimates of birth weight in term women. East Mediterr Health J. 2010;16:313-7 PMID: 20795447.

43. Baum JD, Gussman D, Wirth JC 3rd. Clinical and patient estimation of fetal weight vs. ultrasound estimation. J Reprod Med. 2002:47:194-8 PMID: 11933683.

44. Noumi G, Collado-Khoury F, Bombard A, Julliard K, Weiner Z. Clinical and sonographic estimation of fetal weight performed during labor by residents. Am J Obstet Gynecol. 2005;192:1407-9. https://doi.org/10. 1016/j.ajog.2004.12.043.

45. Barel O, Vaknin Z, Tovbin J, Herman A, Maymon R. Assessment of the accuracy of multiple sonographic fetal weight estimation formulas: a 10year experience from a single center. J Ultrasound Med. 2013;32:815-23. https://doi.org/10.7863/ultra.32.5.815.

46. Curti A, Zanello M, De Maggio I, Moro E, Simonazzi G, Rizzo N, et al. Multivariable evaluation of term birth weight: a comparison between ultrasound biometry and symphysis-fundal height. J Matern Fetal Neonatal Med. 2014;27:1328-32. https://doi.org/10.3109/14767058.2013.858241.

47. Souka AP, Papastefanou I, Michalitsi V, Pilalis A, Kassanos D. Specific formulas improve the estimation of fetal weight by ultrasound scan. J Matern Fetal Neonatal Med. 2014;27:737-42. https://doi.org/10.3109/ 14767058.2013.837877.

48. Thilaganathan B. Ultrasound fetal weight estimation at term may do more harm than good. Ultrasound Obstet Gynecol. 2018;52:5-8. https://doi.org/ 10.1002/uog.19110.

49. Dudley NJ. A systematic review of the ultrasound estimation of fetal weight. Ultrasound Obstet Gynecol. 2005;25:80-9. https://doi.org/10.1002/uog.1751.

Ready to submit your research? Choose BMC and benefit from:

- fast, convenient online submission

- thorough peer review by experienced researchers in your field

- rapid publication on acceptance

- support for research data, including large and complex data types

- gold Open Access which fosters wider collaboration and increased citations

- maximum visibility for your research: over $100 \mathrm{M}$ website views per year

At BMC, research is always in progress.

Learn more biomedcentral.com/submissions 